\title{
Domestic Market Segmentation and Expansion of China's Export Trade
}

\author{
Jing Ma \\ Economic and Trade Department, Xijing University, Xi'an, 710123, China \\ 1234567@163.com
}

Keywords: Market Segmentation, Export Trade, Transition Economies.

\begin{abstract}
The inverse relationship between the domestic market segmentation and between marginal cost and the fixed costs of the introduction of Melitz model, to build an open economy model. Article proves the domestic market segmentation lead to different production technology of choice for companies to enter foreign markets. This seems to explain the strong growth of China's export trade is actually serious domestic companies can not rely on market segmentation lead to huge domestic demand, economies of scale and was forced to exit the distortions.
\end{abstract}

\section{Introduction}

Market segmentation is the US market scientist Wendell Smith (Wendell R.Smith) in the 20th century to the mid-50s. Since the reform and opening up, the Chinese government has been committed to the construction of the socialist market economy. Unified domestic market has been an important target market economic construction. However, in the process of reform, the local government to promote local economic development, protectionist measures have taken place in varying degrees. Chinese markets have some degree of market segmentation phenomenon, hindering the development of market economy. Market segmentation is a departure from market integration and economic phenomenon, mainly referring to the use of administrative power of local governments to foreign companies to enter the local market, local businesses and capital outflow restrictions of behavior.

China's domestic market segmentation serious cause domestic market, the company is not selling products, but by OEM for export, the formation of excessive expansion of China's export trade, which distortions. Melitz implicitly assumes that the domestic market is the integration of all countries, or that the producers in the domestic market only pay less advertising, marketing and other costs can be realized nationwide sales. Obviously, this assumption in the domestic market segmentation serious China is difficult to sustain. Under the tax sharing framework, local governments have strong incentives to foreign products into the set up barriers to protect local companies, and even have a local production of fake and shoddy goods behavior take connivance. Therefore, the production companies to sell their products across the country, must pay in certain entry costs (including advertising, promotion and lobbying and other costs) for each of the fragmented local market, into the cost of these fragmented markets plus the General Logistics Department of the total the cost is enormous. In addition to the domestic market segmentation factors, the technical characteristics of production will have an impact on the enterprise market choice behavior.

\section{Government Behavior and Market Segmentation in the Transformation}

Local Market segmentation refers to the use of administrative power of local governments to foreign vendors, products to enter the local market or local businesses, resources and other restrictions on the flow of foreign or discriminatory behavior. Local Market segmentation is the new contradictions reform and opening up, China's economic transition process arise.

At different stages of reform and opening up, the local market segmentation have different performances. In the initial stage, mainly the direct use of administrative power to local governments split the market, set up barriers to entry and outflow of resources limitations in the latter part of the reform and opening of this situation weakened. Over time, the local market 
segmentation has become more subtle forms, becoming more sophisticated. The existing literature on the performance of the local market segmentation was summarized, including: product protection and blockade; and blockade of the enterprise protection; protection of capital markets; the implementation of the national industrial policy to implement "There are measures under the policy."

Existing research from different angles reveals the main reason for the formation of the local market segmentation: local governments set stakeholders, economic entities, management body in one, is the root cause of the local market segmentation; local ownership of economic regulation right is leading to local market segmentation institutional reasons; fiscal policies led to economic reasons local market segmentation; investment and financing reform also strengthened local intervention in the economy's strength; entry and exit barriers and the formation of reciprocal causation local market segmentation; performance evaluation or rent needs; local government behavior is not eventually leading to local protection specification form.

China's domestic unified market system construction is lagging behind and the market order, as follows: regional market segmentation and local protectionism dismember the single market, the development of product and factor markets development is not synchronized, the market is lack of credit led to market competition is not standardized, resulting in some of the products and government regulation service market monopoly, the domestic market is not in line with the international market, and so on. This is an important part of the next stage of economic reform.

Market segmentation between causality and local government actions, and government action has its own laws. Government Behavior mechanisms for solving domestic market segmentation has practical significance.

In the study of the domestic market and the transition of China's domestic market segmentation, there are two distinct research paths. Chinese scholars tend to focus on the study of the phenomenon during the description and logic of induction, lack the necessary quantitative analysis, the results are often difficult to accurately the degree of development of things. Foreign scholars focus on the use of economic instruments to measure empirical research, but because they do not understand China's national conditions, caliber and other relevant data, and its conclusions are unconvincing. Further research on the domestic market and China's domestic market segmentation transition issues should be toward the path of inductive logic and empirical analysis of development.

\section{Basic Understanding of Chinese Export Trade Expansion}

China's Processing Trade Position in the Global Value Chain Determines the Limited Export of Value-added Products. From a technical point of view the structure of the processing trade, processing trade roughing currently still mainly labor-intensive types of processing, value-added, technology content is not high. Due to historical positioning, processing enterprises mainly focus on low-end products processing and assembly, ignored or did not have enough resources to absorb, research and development, which led to insufficient investment in manufacturing intermediate goods lift capacity thereof; high value-added, high-tech, high foreign exchange earnings processing trade project is relatively small processing enterprises based on the existing resources and technology to create its own independent research and brand need to invest a lot of money, take great risks. In other words, give up the existing profit model (such as OEM) and sales channels, may make current partner becomes a competitor. The consequences caused by this is that certain industries or product positioning China step in the global division of labor in the value chain, showing a lock (lock in) effects. Break the adverse effects of this effect, we need to pay a high price

China's Processing Trade Enterprises with Foreign Investment in our Country's Strategic Goal of Weakening the Comparative Advantage. Because the developed countries have a comparative advantage in the capital and technical elements, they tend to control the production of core technologies significance of the main parts, and the majority of developing countries, even though the formation of a final production capacity, a higher end product of local level, it still does not have a dominant position on the product. For its part, China's foreign direct investment is 
labor-looking type, mainly using our cheap labor to carry out processing and feed processing-oriented processing trade. In our large-scale foreign-funded enterprises engaged in processing trade show that the main motivation for multinational industrial transfer to China is to take advantage of China's labor cost advantages, and China has long tried to lock in its global value chains and other low-end processing and assembly sectors. Results will inevitably cause: on the one hand, our country because the international market with a lot of cheap manufactured goods and continue to be the object of national trade sanctions, restricted the Chinese to enhance the international image of manufacturing; on the other hand, due to the lack of core technology, China's manufacturing industry chain it is difficult to achieve self-extension and improvement, exacerbated internal restructuring of the manufacturing sector's dependence on foreign capital to some extent.

To Enhance the Export Structure Did not Change Our Labor-oriented Elements of Structure Elements. Our foreign-invested enterprises in the entire chain of production in some industrial manufactured goods, some of which are only responsible for the completion of the production processes (the most common is the simple machining or assembly), which basically cut off ties with the domestic industry. Therefore, foreign-invested enterprises export growth is difficult to stimulate domestic industrial production growth. In addition, the size of the various departments of manufacturing output, the foreign-invested enterprises more concentrated in the clothing, leather and fur, electronic communications equipment, and other departments, which are basically labor-intensive production-oriented sectors. The rapid development of processing trade, while greatly promoted the rapid growth of the whole trade volume, but the labor-intensive goods export structure and capital-intensive goods, but to raise the proportion of exports of labor-intensive goods.

\section{Conclusion}

From China's experience of facts, this paper presents the implementation of the domestic market segmentation hypothesis that the presence of the State of opening up foreign markets if the cost of entry between the local market and overseas market entry cost the country between, it will appear in the local market separating equilibrium based on an open economy; if the domestic market is divided into the cost of serious foreign market entry costs lower than the local market, then there will be an open export-based economy separating equilibrium. We believe in an open economy based on exports separating equilibrium may well explain why China is currently a large number of private enterprises through OEM ways to export products, but in the domestic market is not the product sales of anomalies such detour. However, this export-based open economy separating equilibrium due to inability to rely on the domestic market, economies of scale may make Chinese companies to lock in long-term OEM export trade. In other words, it is difficult to form an international well-known brand. This provides a theoretical basis for the central government to increase the punishment of local protectionism and set up a unified national market.

\section{References}

[1] H. Song. What It Means for the World When China Trade Expansion .WTO Tribune,2004, (12).

[2] D.H. Yang. The Influence of China has Become the International World Factory. China Industrial Economy, 2005, (09).

[3] Q. Ma. The Problem and the Development Direction of China's Processing Trade Transformation and Upgrading International Trade, 2005, (02).

[4] F. Gao. Vertical Specialization and Division of Our Position. International Trade, 2005, (03). 